\title{
SISTEM PAKAR PADA PERMAINAN UNTUK MENGUKUR TINGKAT INTELLIGENCE QUOTIENT (IQ) MENGGUNAKAN METODE BINET- SIMON BERBASIS ANDROID
}

\author{
E.N Tamatjita, Mardiana Irawaty, Rio Ramdhani \\ Program Studi Teknik Informatika \\ Sekolah Tinggi Teknologi Adisutjipto Yogyakarta \\ informatika@stta.ac.id
}

\begin{abstract}
The development of mobile technologies very rapidly at this time, can be seen in all areas of human life. It triggers the level of usage of mobile equipment itself, this time in the form of a smartphone gadgets familiar to the adults and children. IQ tests that exist today are still many that are manual and less desirable, especially for the children. With combined by mobile technology and packed into a game, is expected to add to the child's interest and can be used as a means of learning. The test results of 30 respondents, the level of user satisfaction based GUI Display, User Friendly and Final Game IQ Method Using Binet-Simon-Based Mobile, obtained a percentage of $71.31 \%$ keselurahan assessment. Thus Game IQ can be said Good.
\end{abstract}

\section{KeyWords : Game, Intelligence Qoutient (IQ), Binet-Simon, Mobile}

\section{Pendahuluan}

Permasalahan tes intelegensi yang ada pada saat ini diantaranya, masih banyak yang bersifat manual dalam artian tes-tes yang ada saat ini masih mengacu pada lembaran tes yang berisi soal dan tidak interaktif ataupun menarik apabila dihadapkan terutama kepada anak-anak yang masih pada tingkatan usia pra-sekolah. Pelaksanaan dari tes yang sulit dilakukan karena tempat maupun waktunya harus terorganisir terlebih dahulu, dan juga harus didampingi oleh pakar ( ahli ) atau penguji dalam pelaksanaannya. Contohnya saja dalam tes Binet-Simon sendiri, yang di dalamnya terdapat 15 tes, yang dipilih mewakili 4 bidang kognitif utama : penalaran verbal, penalaran abstrak/visual, penalaran kuantitatif, dan memori jangka pendek, yang semua tesnya berbentuk benda fisik maupun lembaran pertanyaan. Dan juga dalam pelaksanaannya dibutuhkan penguji yang amat terlatih.

\section{Metodologi}

\subsection{Tinjauan Pustaka}

Expert System Untuk Mendiagnosa Tingkat Intelligensi (Intelligence Structure) Pada Usia Remaja Dengan Mengunakan Bahasa Pemrograman WAP, (Rini Sovia, dkk., 2012). Tujuan Penelitian ini untuk membuat sebuah sistem pakar (Expert System) untuk tes IQ menggunakan 
bahasa pemrograman WAP, dengan materi tes berbentuk pertanyaan logika, yang diterapkan ke dalam aplikasi mobile [9].

Sistem Pakar Dalam Menentukan Tingkat IQ Anak Yang Mengalami Reterdasi Mental Dengan Mengunakan Metode Certainty Factor (Studi Kasus : Pendidikan SLB/B Karya Murni), (Faresi Daeli, 2013). Tujuan Penelitian ini untuk membuat sebuah sistem pakar untuk tes IQ anak yang mengalami reterdasi mental berdasarkan gejala yang dialami oleh anak dengan menggunakan metode certainty factor, diterapkan kedalam aplikasi desktop [3].

Perancangan Aplikasi Tes IQ Dengan Mengunakan Metode Binet-Simon, (Rizki Hamdhani, 2014). Tujuan Penelitian ini untuk membuat sebuah Tes IQ menggunakan metode Binet-Simon, dengan materi tes berbentuk soal matematika dan logika, diterapkan kedalam aplikasi desktop [4].

\subsection{Landasan Teori}

\subsubsection{Intelegensi dan IQ}

a. Alfred Binet (1857-1911) dan Theodore Simon, inteligensi terdiri dari tiga komponen, yaitu kemampuan untuk mengarahkan pikiran atau tindakan, kemampuan untuk mengubah arah tindakan bila tindakan itu telah dilaksanakan, dan kemampuan untuk mengritik diri sendiri (autocriticism).

b. Lewis Madison Terman pada tahun 1916, mendefinisikan inteligensi sebagai kemampuan seseorang untuk berpikir secara abstrak.

c. David Wechsler, intelegensi adalah kemampuan untuk bertindak secara terarah, berpikir secara rasional, dan menghadapi lingkungannya secara efektif. Secara garis besar dapat disimpulkan bahwa intelegensi adalah suatu kemampuan mental yang melibatkan proses berpikir secara rasional. Oleh karena itu, intelegensi tidak dapat diamati secara langsung, melainkan harus disimpulkan dari berbagai tindakan nyata yang merupakan manifestasi dari proses berpikir rasional itu.

Sedangkan IQ atau Intelligence Quotient adalah skor yang diperoleh dari sebuah alat tes kecerdasan. Dengan demikian, IQ hanya memberikan sedikit indikasi mengenai taraf kecerdasan seseorang dan tidak menggambarkan kecerdasan seseorang secara keseluruhan [1] [8].

\subsubsection{Pengukuran Intelegensi}

Konsep intelegensi Binet-Simon mendapat sumbangan pemikiran dari William Stern, tentang konsep Intelligence Qoutient (IQ), yang akhirnya memunculkan rumus untuk mencari tingkat inteligensi seseorang dengan merasiokan umur mental (Mental Age) dengan umur kronologis (Chronologikal Age), yang ditujukan dengan IQ. Selanjutnya teori tentang IQ ini terkenal sampai sekarang dan masih banyak digunakan oleh para ahli untuk mencari tingkat inteligensi seseorang [8].

William Stern membuat konsep bahwa terdapat rasio antara umur mental dan umur kronologis, dengan rumus IQ sebagai berikut :

$$
\text { (Intelligence Qoutient } \left.=\frac{\text { Mental Age }}{\text { Chronological Age }}\right)
$$


Perhitungan dengan rumus tersebut selalu menghasilkan angka decimal. Untuk menjadikan angkanya bulat, hasil itu harus dikalikan 100, sehingga rumusnya menjadi :

$$
\left(\mathrm{IQ}=\frac{\mathrm{MA}}{\mathrm{CA}} \times 100\right)
$$

\subsection{Perancangan Sistem}

\subsubsection{Diagram Konteks}

Pada Gambar. 1 Diagram Konteks merupakan diagram level tertinggi dari DFD/DAD yang menjelaskan hubungan User dengan Sistem.

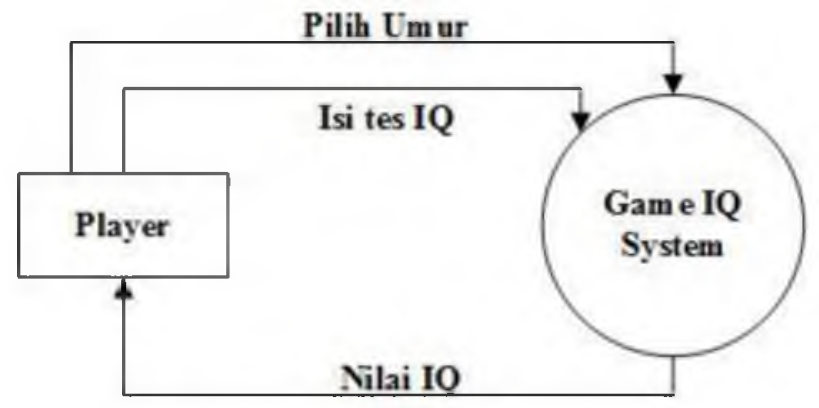

Gambar 1 Diagram Konteks.

\subsubsection{Flowchart Game Intelligence Qoutient (IQ)}

Pada Gambar.2 Flowchart bertujuan untuk menjelaskan urutan kerja atau proses dari program. 


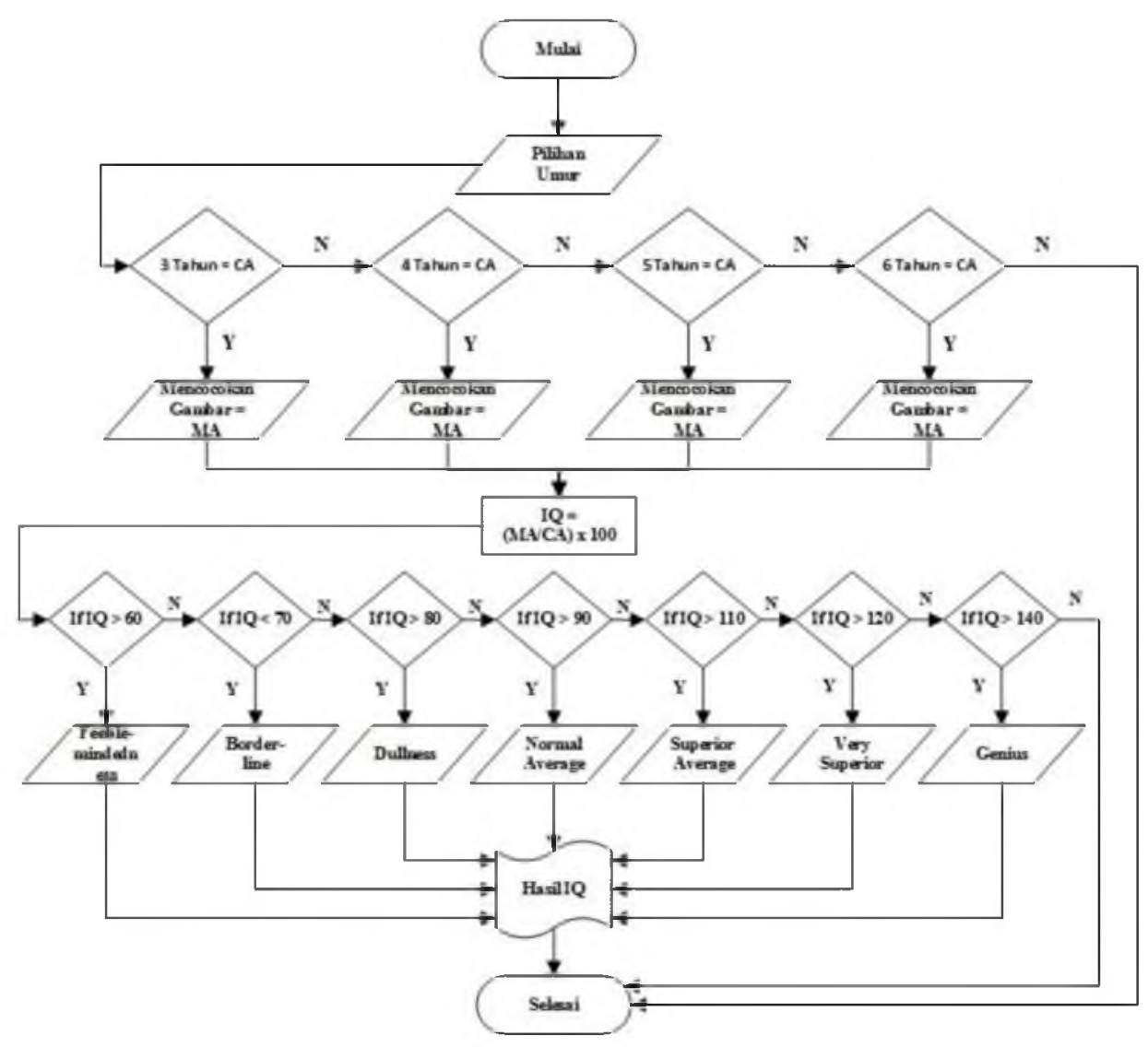

Gambar 2 Flowchart Program

\section{Implementasi Dan Pengujian}

\subsection{Implementasi}

Implementasi merupakan penerapan rancangan sistem yang akan dibuat sesuai dengan perancangan yang terdapat pada bab sebelumnya.

\subsubsection{Implementasi Menu Utama}

Menu utama sendiri berisi pilihan umur peserta Tes IQ. Adapun tampilan menu utama dari game tes IQ yang dibuat seperti tampak pada Gambar 6

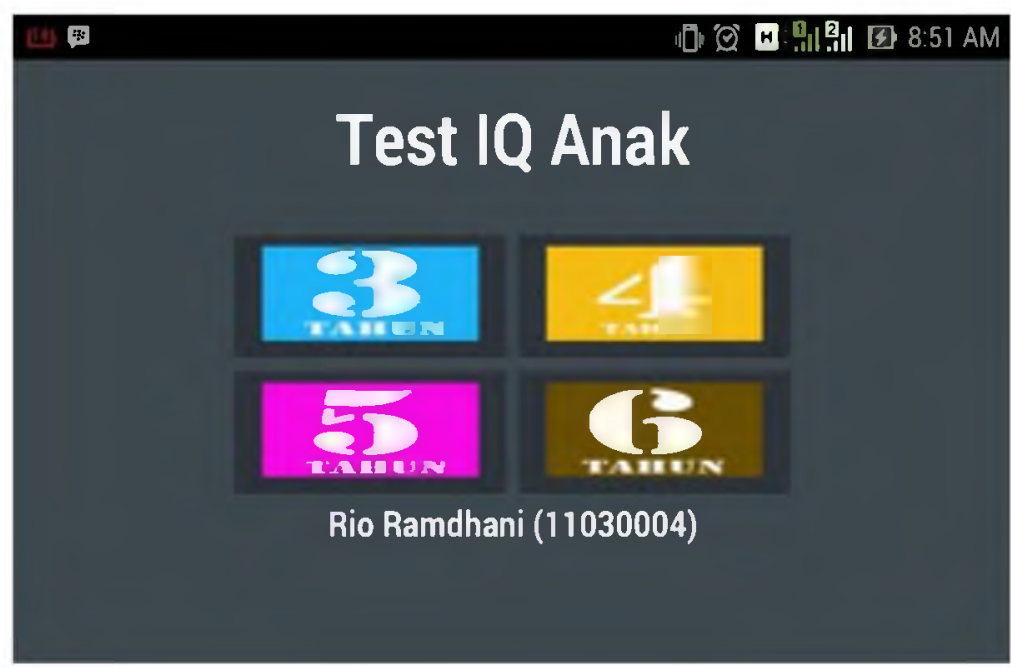

Gambar 6 Implementasi Menu Utama 


\subsubsection{Implementasi Menu Stage}

Dalam Menu Stage sendiri berisi 6 opsi gambar sebagai pilihan jawaban, untuk dicocokkan dengan 1 gambar sebagai soal.

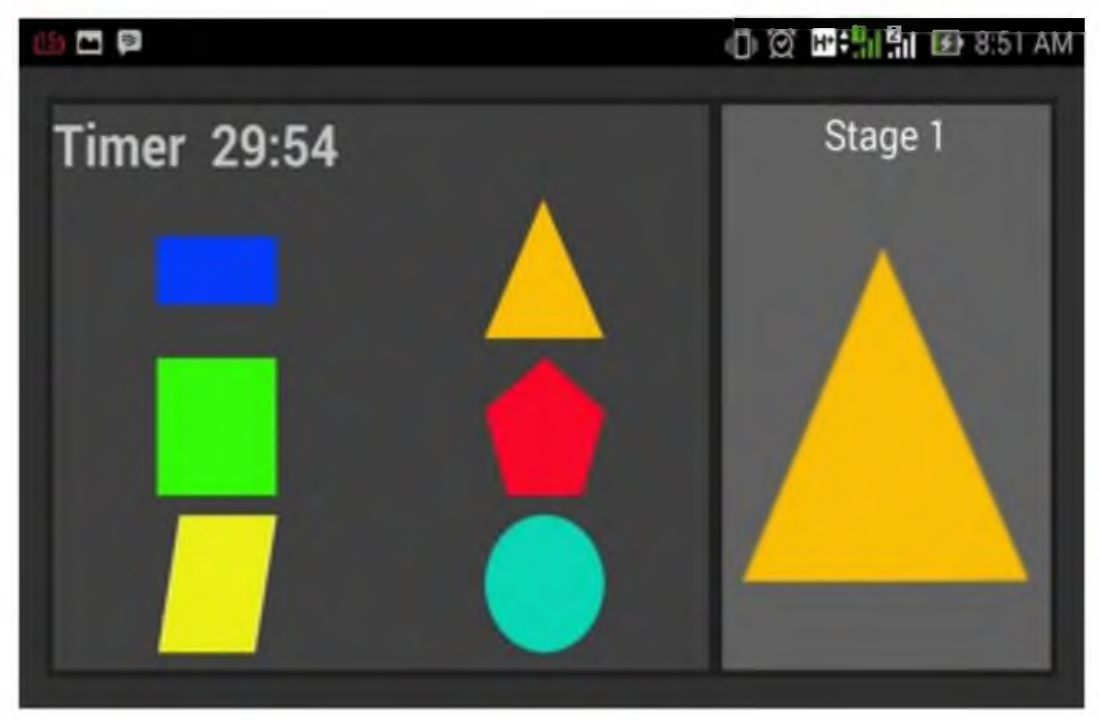

Gambar 7 Implementasi Menu Stage

\subsubsection{Implementasi Menu Hasil Akhir}

Menu Hasil Akhir sendiri berisikan, hasil IQ yang didapat oleh peserta dalam mengerjakan soal yang telah disediakan.

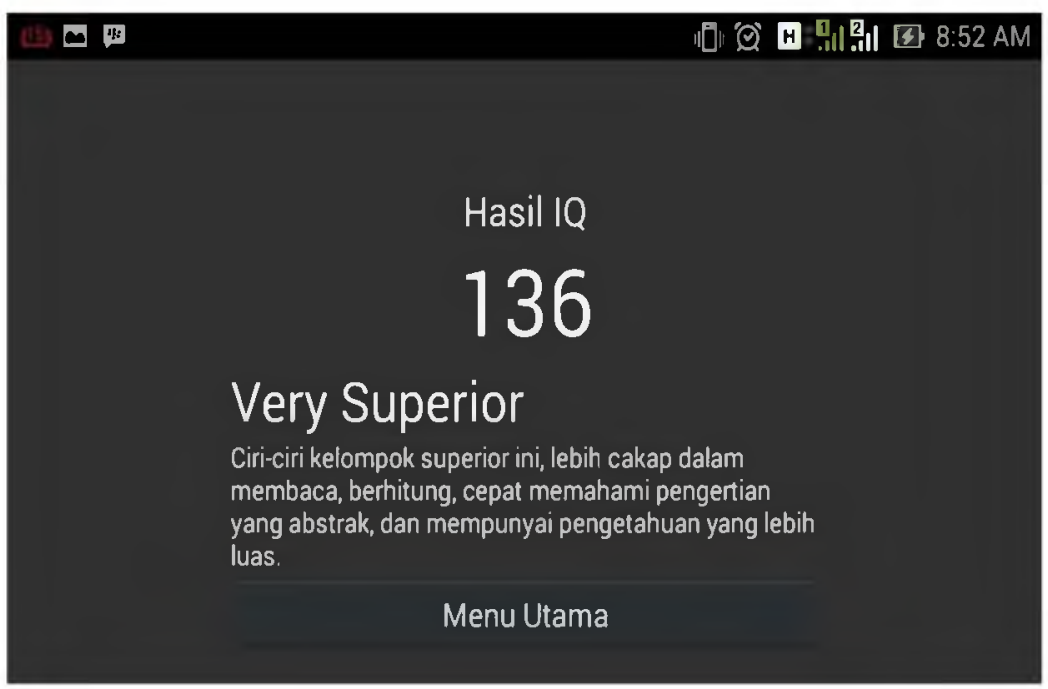

Gambar 8 Implementasi Menu Hasil Akhir 


\subsection{Pengujian}

Pengujian dilakukan untuk mengetahui tingkat kepuasan pengguna dari Game Tes IQ, berdasarkan Tampilan GUI, User Friendly, Hasil Akhir.

\subsubsection{Pengujian Tampilan GUI}

Tabel 1 Hasil Persentase Pengujian Tampilan GUI

\begin{tabular}{|l|l|l|l|l|l|l|l|}
\hline \multirow{2}{*}{ Pertanyaan } & \multicolumn{4}{|l}{ Skor } & \multirow{2}{*}{ Total Skor } & $\begin{array}{l}\text { Persentase } \\
(\%)\end{array}$ \\
\cline { 2 - 7 } & 1 & 2 & 3 & 4 & 5 & & 58.00 \\
\hline 1 & 0 & 14 & 57 & 16 & 0 & 87 & 57.33 \\
\hline 2 & 0 & 18 & 48 & 20 & 0 & 86 & 56.67 \\
\hline 3 & 0 & 18 & 51 & 16 & 0 & 85 & 52.00 \\
\hline 4 & 0 & 26 & 48 & 4 & 0 & 78 & 80.67 \\
\hline 5 & 0 & 0 & 3 & 108 & 10 & 121 & 81.33 \\
\hline 6 & 0 & 0 & 3 & 104 & 15 & 122 & 81.33 \\
\hline 7 & 0 & 0 & 3 & 104 & 15 & 122 & 58.00 \\
\hline 8 & 0 & 6 & 66 & 16 & 5 & 87 & 74.00 \\
\hline 9 & 0 & 0 & 33 & 68 & 10 & 111 & 80.00 \\
\hline 10 & 0 & 0 & 21 & 64 & 35 & 120 & 679.33 \\
\hline \multicolumn{7}{|l|l|l|}{ Total Persentase }
\end{tabular}

Perhitungan Rata-rata pada Pengujian Tampilan GUI Game Tes IQ berdasarkan data di atas seperti tampak di bawah ini :

Rata-rata : Total Persentase / Jumlah Pertanyaan

: $679.33 / 10$

: 67.93

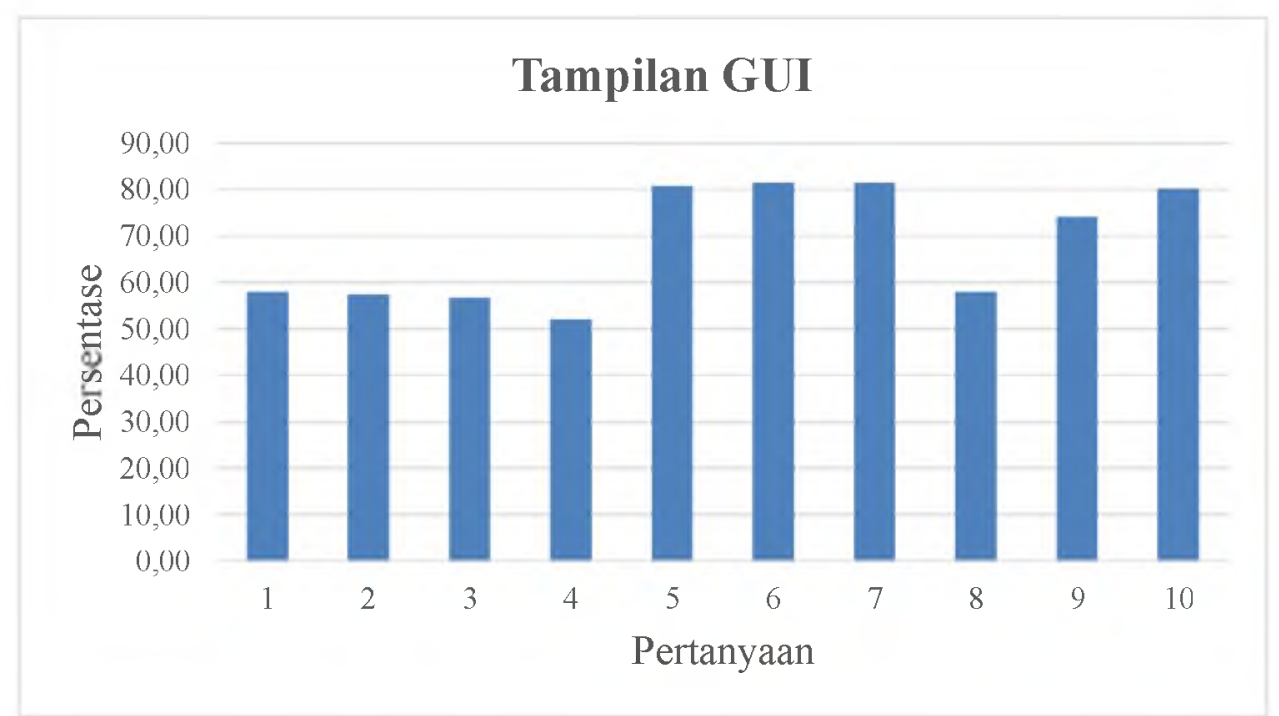

Gambar 9 Grafik Pengujian Tampilan GUI Game Tes IQ

Dari Tabel 2 Hasil Pengujian Tampilan GUI dan Gambar 9 Grafik Pengujian Tampilan GUI Game Tes IQ, hasil rata-rata persentase untuk pengujian Tampilan GUI adalah $67.93 \%$, jika dibandingkan dengan interval yang telah dibuat sebelumnya maka 67.93\% termasuk Baik. 


\subsubsection{Pengujian User Friendly}

Tabel 2 Hasil Persentase Pengujian User Friendly

\begin{tabular}{|l|l|l|l|l|l|l|l|}
\hline \multirow{2}{*}{ Pertanyaan } & \multicolumn{3}{|l}{ Skor } & \multirow{2}{*}{ Total Skor } & $\begin{array}{l}\text { Persentase } \\
(\%)\end{array}$ \\
\cline { 2 - 7 } & 1 & 2 & 3 & 4 & 5 & & 77.33 \\
\hline 1 & 0 & 0 & 15 & 96 & 5 & 116 & 77.33 \\
\hline 2 & 0 & 0 & 12 & 104 & 0 & 116 & 74.00 \\
\hline 3 & 0 & 0 & 27 & 84 & 0 & 111 & 79.33 \\
\hline 4 & 0 & 0 & 9 & 100 & 10 & 119 & 80.67 \\
\hline 5 & 0 & 0 & 3 & 108 & 10 & 121 & 80.67 \\
\hline 6 & 0 & 2 & 3 & 96 & 20 & 121 & 70.67 \\
\hline 7 & 0 & 2 & 36 & 68 & 0 & 106 & 63.33 \\
\hline 8 & 0 & 0 & 75 & 20 & 0 & 95 & 47.33 \\
\hline 9 & 0 & 38 & 33 & 0 & 0 & 71 & 75.33 \\
\hline 10 & 0 & 0 & 24 & 84 & 5 & 113 & 766.00 \\
\hline \multicolumn{7}{|l|}{ Total Persentase }
\end{tabular}

Perhitungan Rata-rata pada Pengujian User Friendly Game Tes IQ berdasarkan data di atas seperti tampak di bawah ini :

Rata-rata : Total Persentase / Jumlah Pertanyaan

$: 766.00 / 10$

$: 76.60$

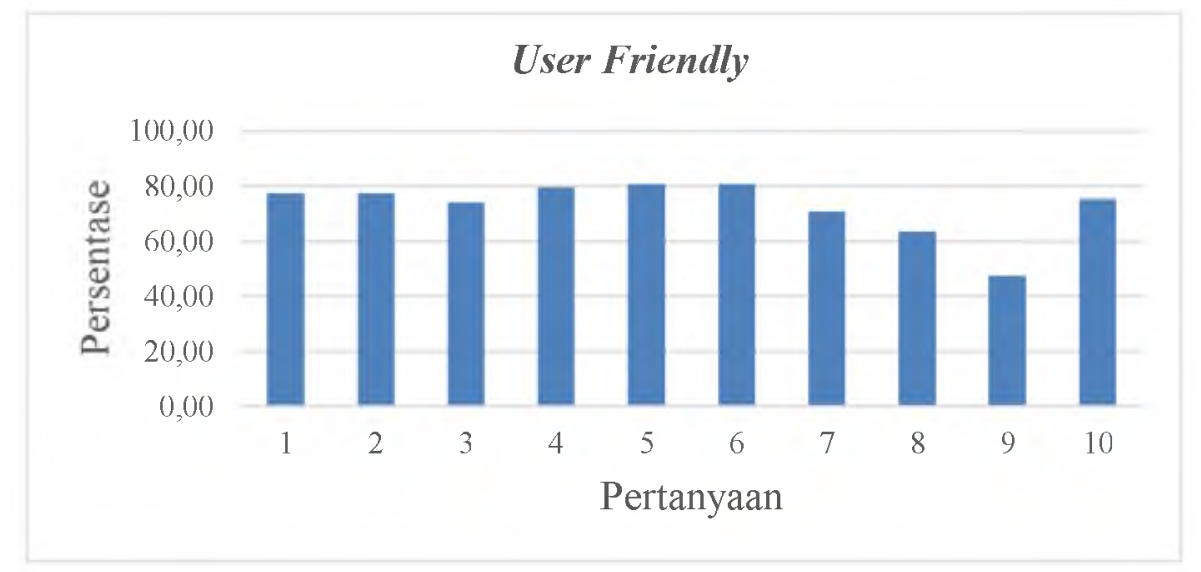

Gambar 10 Grafik Pengujian User friendly Game Tes IQ

Dari Tabel 4 Hasil Pengujian User Friendly dan Gambar 10 Grafik Pengujian User Friendly Game Tes IQ, hasil rata-rata persentase untuk pengujian User Friendly adalah $76.60 \%$, jika dibandingkan dengan interval yang telah dibuat sebelumnya maka 76.60\% termasuk Baik. 


\subsubsection{Pengujian Hasil Akhir Game Tes IQ}

Tabel 3 Hasil Persentase Pengujian Hasil Akhir

\begin{tabular}{|l|l|l|l|l|l|l|l|}
\hline \multirow{2}{*}{ Pertanyaan } & \multicolumn{3}{|l}{ Skor } & \multirow{2}{*}{ Total Skor } & $\begin{array}{l}\text { Persentase } \\
(\%)\end{array}$ \\
\cline { 2 - 7 } & 1 & 2 & 3 & 4 & 5 & & 72.67 \\
\hline 1 & 0 & 0 & 33 & 76 & 0 & 109 & 66.67 \\
\hline 2 & 0 & 0 & 60 & 40 & 0 & 100 & 48.00 \\
\hline 3 & 0 & 0 & 18 & 12 & 0 & 72 & 60.67 \\
\hline 4 & 0 & 42 & 69 & 16 & 0 & 91 & 74.67 \\
\hline 5 & 0 & 6 & 24 & 88 & 0 & 112 & 74.67 \\
\hline 6 & 0 & 0 & 24 & 88 & 0 & 112 & 64.00 \\
\hline 7 & 0 & 0 & 66 & 28 & 0 & 96 & 73.33 \\
\hline 8 & 0 & 2 & 30 & 80 & 0 & 110 & 82.67 \\
\hline 9 & 0 & 0 & 15 & 64 & 45 & 124 & 76.67 \\
\hline 10 & 0 & 0 & 24 & 76 & 15 & 115 & 694.00 \\
\hline \multicolumn{7}{|l|}{ Total Persentase }
\end{tabular}

Perhitungan Rata-rata pada Pengujian Hasil Akhir Game Tes IQ berdasarkan data di atas seperti tampak di bawah ini :

Rata-rata : Total Persentase / Jumlah Pertanyaan

: $694.00 / 10$

: 69.40

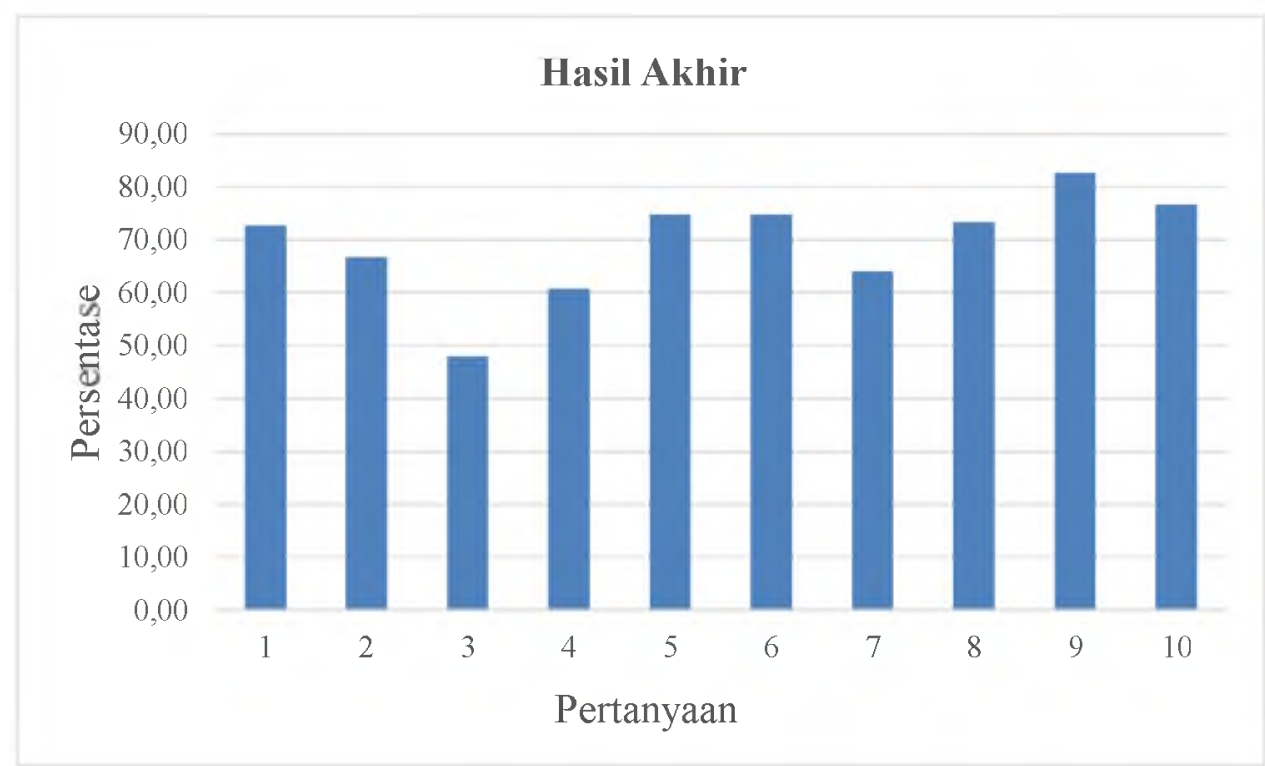

Gambar 11 Grafik Pengujian Hasil Akhir Game Tes IQ

Dari Tabel 6 Hasil Pengujian Hasil Akhir dan Gambar 11 Grafik Pengujian Hasil Akhir Game Tes IQ, hasil rata-rata persentase untuk pengujian Hasil Akhir adalah $69.40 \%$, jika dibandingkan dengan interval yang telah dibuat sebelumnya maka $69.40 \%$ termasuk Baik.

Dari Hasil pengujian terhadap 30 responden yang dilakukan pada murid TK. Angkasa Adisutjipto usia 3-6 tahun, mengenai tingkat kepuasan penguna berdasarkan Tampilan GUI (67.93\%), User Friendly (76.60\%) dan Hasil Akhir (69.40\%) dari Game IQ Mengunakan 
Metode Binet-Simon Berbasis Mobile. Didapatkan persentase rata-rata penilaian keselurahan sebesar 71.31\%, dengan demikian Game IQ tersebut dapat dikatakan Baik.

\section{Penutup}

\subsection{Kesimpulan}

Berdasarkan hasil uji penguna pada murid TK. Angkasa Adisutjipto usia 3-6 tahun, dari Game IQ Mengunakan Metode Binet-Simon Berbasis Mobile. Didapatkan kesimpulan sebagai berikut :

1. Hasil pengujian terhadap 30 responden, mengenai tingkat kepuasan penguna berdasarkan Tampilan GUI, User Friendly dan Hasil Akhir dari Game IQ yang Menggunakan Metode Binet-Simon Berbasis Mobile, didapatkan persentase penilaian keselurahan sebesar 71.31\%. Dengan demikian Game IQ tersebut dapat dikatakan Baik.

2. Berdasarkan hasil uji penguna, bentuk dari tes IQ yang berupa Game berbasis Mobile. Dapat menambah daya minat dan mempermudah akses anak dalam melakukan tes IQ.

3. Serta dapat pula menjadi media atau sarana pembelajaran bagi anak itu sendiri, karena materi atau obyek soal yang digunakan dalam Game IQ berupa pengenalan bentuk bangun datar, benda, buah, hewan, huruf dan angka.

\subsection{Saran}

Adapun beberapa saran dari penulis untuk pengembangan Game IQ Mengunakan Metode Binet-Simon Berbasis Mobile, antara lain :

1. Agar dapat ditambahkan faktor-faktor pendukung lainnya dalam perhitungan IQ, karena dalam perkembangan tingkat kecerdasan anak sendiri, banyak dipengaruhi faktor-faktor external lainnya, sehingga hasil IQ yang didapat lebih baik lagi.

2. Karena game IQ ini hanya dapat berjalan pada sistem operasi Android, ada baiknya bila game IQ ini dapat dijalankan pada sistem operasi lainnya.

3. Game IQ ini hanya memiliki 20 soal/pertanyaan yang tampil secara random, sehingga peserta tidak bisa memainkannya secara berulang-ulang. Jumlah soal yang lebih banyak dapat menambah kegunaan dari game IQ yang dibangun.

\section{Daftar Pustaka}

[1] Anastasi, A., dan Urbina, S. 2007. Tes Psikologi. Jakarta : Indeks, edisi ke tujuh.

[2] Budiaji, Weksi. 2013. Skala Pengukuran Dan Jumlah Respon Skala Likert. No. 2. Vol. 2.23026308 .

[3] Daeli, Faresi. 2013. Sistem Pakar Dalam Menentukan Tingkat IQ Anak Yang Mengalami Reterdasi Mental Dengan Metode Certainty Factor (Studi Kasus : Pendidikan SLB/B Karya Murni). No. 3. Vol. 4.2301-9425.

[4] Hamdani, Rizki. 2014. Peracangan Aplikasi Tes IQ Dengan Mengunakan Metode BinetSimon. No 3. Vol 5.2301-9425.

[5] Herlina, dkk. 2007. Psikodiagnostik IV Inteligensi. Universitas Pendidikan Indonesia.

[6] Jogiyanto H.M. 2006. Analisa dan Desain Sistem Informasi. Penerbit Andi, Yogyakarta.

[7] Kadir, Abdul. 1999. Konsep dan Tuntunan Praktis Basis Data. Penerbit Andi, Yogyakarta 
[8] Nur'aeni. 2012. Tes Psikologi : Tes Intelegensi dan Tes Bakat. Purwekerto: Universitas Muhammadiyah Purwekerto Press.

[9] Sovia, Rini dkk. 2012. Expert Sistem Untuk Mendiagnosa Tingkat Intelligensi (Intelligence Structure Test) Pada Usia Remaja Dengan Mengunakan Bahasa Pemrograman WAP" No 2. Vol 5.2086-4981.

[10] Terman, Lewis M. 2007. The Measurement Of Intelligence. ISO-8859-1. 